\title{
The Known Unknowns: What Citizen Science Projects in Germany Know about Their Volunteers-And What They Don't Know
}

\author{
Nicola Moczek ${ }^{1,2, *}$, Susanne Hecker ${ }^{1}$ and Silke L. Voigt-Heucke ${ }^{1,3}$ \\ 1 Museum für Naturkunde Berlin, Leibniz Institute for Evolution and Biodiversity Science, Invalidenstraße 43, \\ 10115 Berlin, Germany; Susanne.Hecker@mfn.berlin (S.H.); Silke.Voigt-Heucke@mfn.berlin (S.L.V.-H.) \\ 2 PSY:PLAN Institute for Architectural and Environmental Psychology, 10245 Berlin, Germany \\ 3 Animal Behaviour, Institute of Biology, Freie Universität Berlin, Takustr. 6, 14195 Berlin, Germany \\ * Correspondence: Nicola.Moczek@mfn.berlin
}

\section{check for} updates

Citation: Moczek, N.; Hecker, S.; Voigt-Heucke, S.L. The Known

Unknowns: What Citizen Science Projects in Germany Know about Their Volunteers-And What They Don't Know. Sustainability 2021, 13, 11553. https://doi.org/10.3390/ su132011553

Academic Editors: Leonie Dendler, Annett Schulze, Stefan Böschen and Claudia Göbel

Received: 29 July 2021

Accepted: 15 October 2021

Published: 19 October 2021

Publisher's Note: MDPI stays neutral with regard to jurisdictional claims in published maps and institutional affiliations.

Copyright: (c) 2021 by the authors. Licensee MDPI, Basel, Switzerland. This article is an open access article distributed under the terms and conditions of the Creative Commons Attribution (CC BY) license (https:// creativecommons.org/licenses/by/ $4.0 /)$.

\begin{abstract}
The citizen science landscape in Germany offers an enormous range for participation. More than 170 projects currently present themselves on the national citizen science platform. In 2020, we conducted a survey among 140 projects (participation rate 56\%), and they provided information on the organisational framework and characteristics (disciplines, initiators, funding, and project goals), as well as on the academic researchers and the volunteering citizen scientists involved. A surprising result was that the level of knowledge about the volunteers is very low overall. Many projects deliberately do not collect personal data (e.g., on socio-demographic variables, knowledge, and behaviour), partly for data-protection reasons and partly because they are unsure about how to collect it due to a lack of instruments and standards. We aim to illustrate the complexity of this issue and discuss various dilemmas arising between theoretical aspirations and the pragmatic and procedural realities in practice. We conclude with suggestions for developing project-specific strategies to increase diversity and inclusion. We argue that the task of conducting accompanying research on participant diversity cannot be borne by individual projects alone and consider the development and implementation of co-creative and qualitative approaches suitable for this purpose.
\end{abstract}

Keywords: participation; citizen science; volunteering; inclusiveness; public engagement; volunteer management; participant demographics

\section{Introduction}

Academic research opens up to the public through various forms of participation, and very many people are willing to participate. This cooperation plays a key role in the joint development of solutions to the major societal challenges of our time. According to the ECSA "10 Principles of Citizen Science" [1] and the "Characteristics of Citizen Science" [2,3] academic researchers, citizens, enablers, and other project participants may take up different roles and responsibilities in citizen science projects. Various frameworks have studied, in particular, the roles of citizens. Shirk et al. (2012), for example, propose tiered models in which the level of involvement ranges from very low to very high [4]. In participatory research projects, there are contexts in which academic researchers and citizens act as equal partners and those in which the contribution of citizens is limited to data collection or the provision of resources. It is an important concern to create transparency regarding the different roles and expectations in the research process and to create awareness among all participants that they are making-regardless of whether their role is small or large- a contribution to the research and the creation of new knowledge [2].

\subsection{Inclusiveness and Diversity in Citizen Science Projects}

Increasingly, the citizen science community is formulating the demand and desire to make the group of participants from science and society as diverse as possible, e.g., [5,6]. 
Cooper et al. (2020) have just brought the discussion about the claims to inclusiveness and terminology of citizen science into focus [7]. This is backed by the United Nations Sustainable Development Goals (SDGs) and the principle of "leaving no one behind" (LNOB) [8]. The European Commission also strives to define research and sustainable innovation mandates based on an "inclusive process" [9].

In academic research, there are many different understandings and different ways of defining and operationalising inclusion [10]. In a German survey among 182 teachers, the most frequently found categories related to participation and membership or differentiation and individualisation. However, other categories were also found on social, ethical, and educational aspects, as well as affective aspects and (negative) evaluations [10]. While the topic of inclusion is discussed widely at the European level [11], it is not yet explicitly addressed at the level of the citizen science community in Germany [12]. To the best of our knowledge, there is not yet a single definition of inclusion that the German citizen science community would refer to. There is, however, an awareness of the importance of inclusion and diversity, but when it comes to implementation, it is usually only addressed as "diversity" at the level of volunteer management [12] (pp. 25, 42, and 46). As a result, diversity on the part of the researchers or other groups involved is rarely taken into account.

We therefore note a deficiency at this point. As mentioned above, inclusiveness is often equated with the diversity of the volunteers. It can "be examined along different axes such as gender, ethnicity, socio-economic and sociocultural status, location, and educational level, alongside how these axes intersect to define hierarchies and power relations [13] (p. 262)".

With our article, we would like to give an overview of the current status of participant diversity in Germany. We analyse the pragmatic and not yet theorised way citizen science projects deal with inclusiveness in practice. We focus mainly on the volunteers in citizen science projects to better understand some of the specific challenges and dilemmas related to key social issues, such as the knowledge of diversity and inclusion in citizen science projects.

We will start with a short history of volunteering (Section 1.2) followed by a recap of two representative German surveys on volunteering (Section 1.3) before we take a closer look at the German citizen science platform (Section 1.4).

\subsection{Short History of Volunteering and Participation in Research in Germany}

In Germany, the roots of voluntary scientific research go back some 275 years [14-18], and their role only changed after the establishment of the empirical natural sciences [17]. Daum (2002) provided a comprehensive compilation of the popularisation of science in the 19th century [15] and highlighted the at times very close relationship between academic science and "popular science" (e.g., the term he uses for the concept citizen science).

In the natural sciences, for example, voluntary structures have been organised locally, regionally, or even throughout the country since the late 19th century to support state and academic researchers $[16,17,19]$. The "Nature Conservation and Landscape Management Act" (Ger.: Bundesnaturschutzgesetz, BNatSchG) has formed the legal basis since 1976. Since 1994, environmental protection has been enshrined in the Constitutional Law and thus elevated to a state objective. The implementation of nature conservation has thus become a task for German society as a whole. In 1992, the "Convention on Biological Diversity" (CBD) was adopted at the "United Nations Conference on Environment and Development" (UNCED) in Rio de Janeiro; Germany ratified it in 1993. In Germany, the "National Strategy on Biological Diversity" (NBS) was adopted by cabinet resolution on 7 November 2007; the action targets extend to the year 2050 [20] (pp. 6-7).

An essential component of the NBS is a regular performance review or monitoring based on a set of indicators, for which a report is to be submitted in each legislative period. The federal states are responsible for collecting data on the status and development of biological diversity. However, they are also dependent on the active assistance of many volunteers for data collection and monitoring [20], p. 138, because the work is very time- 
consuming and requires regular monitoring by knowledgeable experts at many different locations. The "Federal Ministry for the Environment, Nature Conservation, Building and Nuclear Safety" (BMUB) has been naming these activities as "citizen science" since 2007 [20]. Volunteering is an essential, required pillar of nature conservation in Germany, but also other scientific disciplines, such as the work in museums, archives, and libraries can largely only be carried out with the support of volunteers.

\subsection{German Nationwide Surveys on Volunteering}

Despite this long tradition of volunteering and participation in research in Germany, there are no representative cross-sectional studies for citizen science. Nevertheless, there is good knowledge about volunteering in Germany. Conducted for the first time in 1999 on behalf of the "Federal Ministry for Family Affairs, Senior Citizens, Women and Youth", the "German Survey on Volunteering" has been repeated every five years since then. The 4th German Volunteer Survey took place in 2014. In total, 28,689 people over 14 years were interviewed for this representative study [21]. The 5th survey mapped volunteering in 2019 and resulted in a sample size of 27,762 persons aged 14 and older [22]. The results showed that volunteering in Germany is at a high level. In 2019, as in 2014, around 40\% of people in Germany engaged in voluntary work, the equivalent of around 28.8 million people, compared to $30.9 \%$ in 1999 . In 2014, it was stated that for some groups the opportunities for participation were unequal. These groups were women, people of higher age, people with a low education level, people with health limitations, and people with a migration background [21]. For the first time since 1999, in 2019 no statistically significant difference was measurable in volunteering among women $(39.2 \%)$ and men $(40.2 \%)$. However, participation in volunteering still differs by age. While the proportion of volunteers has increased in all age groups since 1999, the strongest increase can be found in the group of people aged 65 and over. In this age group, the engagement rate has increased from $18.0 \%$ in 1999 to $31.2 \%$ in 2019 [22]. The engagement rate for people with a high school education is $51.1 \%$; for people with a medium level of education, $37.4 \%$; and for people with a low level of education, $26.3 \%$. Educational differences in volunteering have increased between 1999 and 2019 . While $44.4 \%$ of people without a migration background are involved, only $27.0 \%$ of people with a migration background are involved. However, the proportion of people with a migration background who were born in Germany and have German citizenship who are involved in volunteering is 38.7\% in 2019 [22].

Involvement takes place in many different areas and benefits different target groups. Most people are involved in the area of sport and exercise with $13.5 \%$. This is followed by culture and music with $8.6 \%$, the social sector with $8.3 \%$, and school and kindergarten with $8.2 \%$. In $2019,3.5 \%$ of volunteers said they were involved in the protection of the environment, nature, or animals. Today, volunteers spend proportionately less time on their commitment than twenty years ago. Fifty-seven percent of volunteers use the internet as part of their voluntary activities. A good half of these volunteers use the internet in an active way for their voluntary work, for example, by participating in social networks or blogs, creating newsletters and online reports, or maintaining the homepage of their association or organisation [22].

\subsection{The German Citizen Science Platform "Bürger Schaffen Wissen"}

The German-speaking countries of Germany, Austria, and Switzerland are among the countries in Europe where citizen science is structurally well anchored with national platforms and networks. In June 2021, each of these countries run their own platform to present citizen science as a field, as well as projects, to a broad public. Such platforms help to increase the visibility and outreach of citizen science projects to citizens, the media, policy-makers, and funding bodies at the national level. They also offer project managers a variety of opportunities for networking and professional exchange through annual conferences and working groups [23-25]. 
The German citizen science platform "Bürger schaffen Wissen" (Eng.: Citizens Create Knowledge) has been online since April 2014. It is jointly operated by the Museum für Naturkunde Berlin (MfN) and Wissenschaft im Dialog gGmbH (WiD). The project has been receiving funding from the Federal Ministry of Education and Research (BMBF) since 2013. The platform is the result of an initiative by institutions of the Helmholtz and Leibniz Associations with their university and non-university collaborates [24].

At the end of 2016, a study on the projects presented on the Austrian and German national citizen science platforms was carried out by Pettibone et al. [24]. In a quantitative desktop analysis, all 72 projects listed at that time were systematically examined for characteristics such as the institutional ties of the project operators or scientific disciplines. For this purpose, the authors assigned the respective projects to the scientific disciplines in which they considered a scientific publication to be most likely. According to this analysis, biology, including the research areas biodiversity, zoology, and botany, was the most represented discipline with $42 \%$. Historical research accounted for $16.5 \%$, non-biological natural sciences such as chemistry and astronomy $15.5 \%$, geography $13.4 \%$, health research $6.2 \%$, other humanities and social sciences $3.1 \%$, and other research disciplines $3.1 \%$. Taken as a whole, $40 \%$ of the projects were coordinated by societal actors such as non-profit advocacy groups, independent scientific organisations, or engaged individuals. Pettibone's et al. focus was on the question of the scientific side; the study gives almost no answers about who the acting citizen scientists are.

\section{Theoretical Background}

Following the pragmatic definition of diversity and inclusiveness, we first take a closer look at some case studies referring to gender and educational level (Section 2.1). We summarise the level and quality of participation and relate it to the level of skills and expertise, as well as to the volunteers' degree of autonomy in carrying out the activities (Section 2.2). Finally, we present findings on hierarchies and power relations between academic researchers and volunteers and discuss different terms for participatory research (Section 2.3).

\subsection{Case Studies with Reference to the Diversity of the Participants}

In our literature research, we found that today there are only a few published studies in Germany that refer explicitly to the diversity of the volunteers. (However, we would like to point out that we have not carried out a systematic evaluation of project reports or documentation.) In the following, we present exemplarily four German case studies and focus on gender and educational status: in the survey of the "German Mosquito Atlas" project, 118 out of 150 people took part in a survey $(78.6 \%)$, of which $67.9 \%$ were male and $32.1 \%$ female, and $50.90 \%$ with high school graduation [26]. In the accompanying research for the citizen science scheme "Insects of Saxony", the response rate in 2018 was $57.4 \%(N=116)$, of which $71.6 \%$ were male and $26.7 \%$ female, with an average age of 52.3 years and $70 \%$ with an academic degree [27]. In the citizen science scheme "Wildcats in Germany", the response rate in 2016 was $27.1 \%(N=209)$, of which $66.6 \%$ were male and $33.3 \%$ female, with an average age of 55.9 years and $71 \%$ with an academic degree [19]. For both projects-Insects of Saxony and Wildcats-very detailed descriptions of the participants are available, as well as on places of residence and city-country distribution; educational status; prior knowledge; knowledge gain; and, above all, the motives for participation. In the scheme "Wildlife Researchers", no response rate was published, but the dropout rate between the first and the second survey was $43.7 \%$. The datasets of 303 participants could be analysed, of which were $41.3 \%$ male, $58.4 \%$ female, and $66.7 \%$ with an academic degree [28]. Even though these response rates seem to be quite high overall, they are self-selected samples and therefore they provide only a limited picture of the diversity of the participants. The data support the image of male and well-educated participants. 
Because we do not have representative studies on citizen science in Germany, we take briefly examine Great Britain and Switzerland. Pateman, Dyke, and West 2015 examined in a study representative of the United Kingdom which groups of people participate in citizen science projects; 8220 people were surveyed, of whom 613 (i.e., $7.5 \%$ of the total sample) reported having participated in a citizen science environmental project, and 321 participated in more than one project. People who identified themselves as belonging to white ethnic groups were more likely to participate than those who identified themselves as belonging to ethnic minority groups; participation by ethnic minority women was particularly low. Participation among members of white ethnic groups decreased with socio-economic status, while this was not the case for members of ethnic minorities. Participation was highest among those in education (at school, college, or university) and lowest among the unemployed [5]. A recent study, which is also representative, investigated the willingness of the Swiss resident population aged 18 and over to participate in research. For this purpose, 1394 interviews were conducted: $15 \%$ of the respondents were familiar with the term "participatory research", and 5\% of them had already taken part in a participatory research project. Overall, high potential can be seen, as $48 \%$ of the respondents could imagine participating in participatory research projects. Younger people, people with a higher education, and people with an openness to scientific topics are particularly interested. There are no significant urban/rural differences [29].

\subsection{Level and Quality of Participation in Citizen Science Projects}

Shirk et al. (2012), with their qualitative, five-stage model "Public Participation in Scientific Research" (PPSR), defined the level of participation as the extent to which individuals are involved in the process of scientific research [4]. They thus focused on the process of scientific research and suggested possible roles and or activities for citizen scientists, which are often used to name the respective project type. The development of the ECSA characteristics of citizen science by Haklay et al. [3] shows a very promising new approach. The characteristics were developed through the involvement of the interested community in citizen science. The authors developed a vignette study to ask what kind of activities people would call citizen science. For that purpose, they created a framework of 10 factors and 61 sub-factors that can influence the decision of what is considered citizen science or not. More than 330 respondents from different parts of the world rated the vignette cases. The quantitative and qualitative results showed the complexities and range of views on different case studies. A central element of "Doing It Together" Science (DITOs) was " ... the escalator model of engagement, in which people can enter at a level of participation that matches their needs, interests, and abilities, while also encouraging them to move beyond" [30]. The escalator model of participation, however, has also been critically discussed in other contexts of application. For example, van de Gevel and colleagues noted that in agricultural projects that use participatory research, these categorisations are also used as a normative stance ("more is always better"). They stated that participation often occurs on a "single axis of relative power or influence of researchers versus farmers". And they criticised a lack of reflexive research on participation itself [31].

In practice, the extent to which citizens can or want to move and develop between different roles and activities, or even consciously or unconsciously remain at one of the levels, is handled very differently by the individuals and/or the projects. This was underlined in a German longitudinal study in a project on urban wildlife ecology with the aim of unravelling the knowledge-attitude relationship [28]. On the other hand, we know, especially from the many biodiversity monitoring projects, that they also rely on the voluntary cooperation of people who already have a high level of expertise. In some cases, their expertise is even higher than on the "professional" side-or there are no longer any employed, institutional professionals in the field at all, e.g., [19,32,33].

The qualitative level of volunteer participation can be analysed at the level of research activities. A high degree of self-determination, or autonomy, is seen as an important component of successful volunteering. These activities are usually carried out for their own 
sake, out of interest and pleasure on the part of the subject and are perceived as intrinsically motivated [34-36]. This contrasts with paid employment for many people, which can be characterised by a lack of self-determination (or an experience of being controlled and externally determined). In such cases, extrinsic motives dominate, and the maintenance of activities requires external (coming from outside) impulses [34]. With the help of the self-determination theory (SDT), the quality of motivation to perform certain activities can be described [37]. The core of the theory is the description of three central human needs: the need for autonomy, for competence, and for relationships. The results of various studies on citizen science projects in the biodiversity context support the assumption that voluntary engagement is or can be associated with a high degree of experienced autonomy, e.g., [19].

Depending on the research question and the project, however, it may be useful and necessary to supplement or even replace self-determined research with a task-led approach [38]. In this approach, which was, for example, used by "The Royal Society for the Protection of Birds", the project leaders first describe the future tasks and activities of the citizen scientists as precisely as possible and then look for volunteers with corresponding knowledge, relevant experience, existing skills, and individual motivation for these specific tasks. So, some projects offer further training, for example, for reading old German manuscripts, identifying the species of rare algae, or carrying out environmental analyses. Some projects also equip their volunteers with appropriate material and tools, for example, wildlife cameras or detectors to convert ultrasonic sounds into frequencies audible to humans and instruct them in their use.

\subsection{Hierarchies and Power Relations between Academic Researchers and the Volunteers}

In functionally differentiated societies, academics maintain a strict regime that is closely linked to the professional role of the academic researcher. Membership of this group is made possible by years of university education but is ultimately also dependent on whether or not the person obtains affiliation in an academic institution. This creates a potential conflict for academic researchers when people without these years of qualification are suddenly integrated into the project on an equal footing, e.g., $[39,40]$. Therefore, new terms had to be coined for "invited and non-invited participation" and the inclusion of non-academic researchers in knowledge production [40]. The question of how to refer to volunteer researchers has been debated for some time, e.g., [7] as well as the tensions of cooperation $[15,40]$. The competitive relationship between academic researchers and the citizen scientists manifests itself, for example, when citizen scientists withhold their data and/or findings from the scientific communities or, conversely, commercially successful or critical works by citizen scientists are possibly rejected by the academic world.

It thus becomes clear that the choice of a term can indeed both include and exclude people and/or groups $[7,40,41]$. In fact, terms have also been coined by academic researchers that devalue the work of citizen scientists, in particular, autonomous and "uninvited" researching citizens. These terms include (in parts depreciating) concepts such as the "amateur", "layman", "hobby researchers", or more specific names with a clear negative connotation such as the "Heimathirsch" (eng.: home stag, [42]) for hobby archaeologists. This is to denote a lack of professional status and is the direct result of "boundary work" to separate science from non-science (Gieryn 1983, cited after [41]).

In Germany, today the English term "citizen science" is used almost equally alongside the German translation "Bürgerwissenschaft" or "Bürgerforschung". The English term has the advantage of being gender-neutral. The German term, in the direct meaning, refers only to the male part of the population. The use of the term citizen (Ger.: Bürger) also resonates with "city" and with "Bildungsbürgertum" [43]. This concept refers to a social class of the intellectual and economic upper bourgeoisie living in cities that emerged in mid-18th century in Germany sharing an educational ideal based on idealistic values and classical antiquity. The ideals were inter-connected to Wilhelm von Humboldt and the establishing of modern universities, including the Humboldt-University in Berlin (for 
an overview see also Vohland et al. [44]. In Germany, the citizen science community is currently discussing the term Bürgerwissenschaft, on the one hand because it is not genderneutral and on the other hand because it could also exclude people who do not have legal status as citizens, in the sense of nationals, in Germany. This proportion is surprisingly high. (Regarding voter eligibility, the following picture emerges for the capital Berlin alone: 3.77 million people live in the city, but only 2.47 million are eligible to vote $(65.5 \%)$, including 789,000 people with non-German citizenship and the group of children and young people under 18. Conversely, this could mean that a good third of the population does not feel like citizens, but residents [45]). Other terms, mainly in the American context, are "civic science", "neighborhood science", "community engaged research", "communityowned and managed research", "street science", and "community science" [7]. Liebenberg and colleagues (2021) from different countries and backgrounds propose "tracking science" as a new term that they understand as more inclusive than the term citizen science. Their proposal is explicitly set against a postcolonial political backdrop and major migrations in which "citizen" is becoming an increasingly contested term. They consider the term to be all-inclusive, so that it could be embraced by anyone who participates in or contributes, regardless of socio-cultural background [46].

These terms do not translate easily into German. Moreover, Cooper et al. (2021) explicitly recommended "The term community science should be reserved for projects that focus on local priorities and local perspectives and are able to maintain the locus of power in the community" [7] (p. 2).

\section{Materials and Methods}

\subsection{Guiding Questions of the Explorative Platform Survey}

As outlined, to date, there is a lack of first-hand information on the citizen science landscape and its actors in Germany.

As a scientific partner in the coordination of the German citizen science platform "Bürger schaffen Wissen", a team of researchers at Museum für Naturkunde Berlin (the authors of this article) conducted the survey in order to collect additional features and characteristics of the platform's citizen science projects to optimise the consultation of the projects, advance the development of the platform in terms of content and structure, and identify further research questions and perspectives in the field of science of citizen science.

In this article, we focus on the following overarching questions to better understand diversity, representativeness, and inclusion of volunteers in German Citizen Science projects:

1. What does the current project landscape look like? Which scientific disciplines are represented, who initiates the projects, and how are they funded?

2. How are citizen science projects staffed? Who comprises the scientific staff, and what roles do volunteers take/are volunteers assigned? What do the projects know about diversity and inclusiveness of the volunteers? What levels of participation are offered for volunteers? How do projects organise and share the various scientific tasks?

3. Do projects conduct accompanying research and what methods do they use?

\subsection{Development and Structure of the Questionnaire}

We developed a questionnaire in several steps between March and June 2020 to collect features and characteristics.

The questionnaire was split into six thematic sections: project structure, research, communication, participants, evaluation and, in summary, an assessment of satisfaction on selected aspects such as staffing. Most of the questions could be addressed by selecting preformulated answers ("single-item-measures" with single or multiple answer options). The survey was not anonymous (see Section 2.2). Therefore, we largely refrained from asking questions about personal assessments and essentially asked for characteristics and facts at the project level. The programming did not force participants to answer, so questions could also be skipped. For a few questions, there was a filter function that included or excluded 
further questions depending on the answer behaviour. In addition, we offered open text boxes in each section for additional answers and comments in an open text format.

\subsection{Implementation of the Survey}

The online questionnaire was designed using the programme SoSci Survey [47]. This programme is especially designed for social science surveys and offers data storage on a German server according to German law General Data Protection Regulation, GDPR; [48].

Our goal was a full cross-sectional survey study. We wanted to interview only one responsible person for each project. Starting from 15 July 2020, we sent the invitation to participate personally to the 140 project coordinators who act as contact persons on the platform and whose projects were active at the time to our knowledge. Invitations were sent out by email with a direct link to the survey. The survey was not anonymous as we asked for project name information. We were therefore able to check the response rate and send weekly personal reminders only to those who had not yet participated. Due to the slow response, we extended the survey period up to and including 25 September and contacted the projects by phone. At that time, Germany was in a COVID 19-related lockdown and most people had to work from their home offices.

\subsection{Supplementary Experiences}

As part of our activities for the platform, the team of authors consults citizen science projects in all phases. At the individual level, the most intensive contact takes place at the beginning of the projects' recruitment phase. During this time, many turn to us to discuss issues of recruiting volunteers, communication, motivation, project organisation, etc. In addition, we support capacity building through exchange of knowledge and experience with various formats, including an annual conference, training workshops, and networking groups [25]. Through this close collaboration, we complement the empirical data based on broad experience but methodologically mostly at an anecdotal level.

\section{Results}

The questionnaire was accessed 125 times. Twice, consent to process the data were not given, which led to the automated termination of the survey. In another 43 data sets, participants did not provide any or no usable information. One project took part in the survey twice but only completed one of the two surveys. These 46 data records were deleted from the data set and not included in the analysis. This results in a valid data set for 79 projects, which corresponds to a response rate of $56 \%$. The data were largely analysed on a descriptive level.

\subsection{Characteristics of the Citizen Science Projects}

Of the 79 participating projects, four projects were scheduled for less than one year $(5 \%)$. Twenty-four projects responded to participate for between one and four years (30.4\%). Seven projects have been running for more than five years (8.9\%).

Multiple answers were possible for the question about the location of the research. 78 projects gave 150 answers, so the following percentages add up to more than $100 \%$. $44.9 \%$ of the projects take place nationwide, $37.2 \%$ internationally or globally, and a further $37.2 \%$ virtually.

\subsubsection{Scientific Disciplines}

We asked the project managers to allocate their project to 44 disciplines and offered multiple answers as many work inter- or transdisciplinary. Seventy-eight projects named one hundred and eighty subjects. On average, each project assigned itself to 2.3 disciplines. In a second step, these disciplines were categorised (see Appendix A Table A1). The natural sciences were selected most frequently (112), with biology being selected 67 times. Cultural sciences came second (24), followed by the social sciences and humanities (22), 
engineering and planning (13), and mathematics and computer science (9). No project selected economics or law.

\subsubsection{Project Initiators and Funding}

The majority of projects were started by one initiator (56 projects, $70.9 \%$ ). Another 14 mention two (17.7\%); six, three (7.6\%); and two, four initiators (2.5\%). One project made no statement. In total, 96 initiators were named. In a second evaluation step, the initiators named were categorised. Nine categories were derived. Thirty-three projects were initiated by research institutions and another 30 by universities or colleges. Eighteen projects $(22.7 \%)$ were initiated by associations, interest groups, NGOs, or foundations; another ten by public authorities $(12.6 \%)$; three by private individuals; and one project each by the media, schools, and companies. No project was started by an independent scientific group (Ger: Fachgesellschaft).

Seventy projects provided information on funding. Of these, 26 (37.1\%) are working without external funding. Three projects were in an application phase for funding $(4.3 \%)$. Of the remaining 41 projects, $23(32.9 \%)$ received funding from the German Federal Ministry of Education and Research (BMBF), ten projects (14.3\%) received funding from German foundations, five $(7.1 \%)$ received EU funding, two $(2.9 \%)$ received funding through crowdfunding, and one project (1.4\%) received funding through the German Federal Agency for Nature Conservation (BfN). A supplementary evaluation was carried out separately for the scientific disciplines. This shows that the proportion of external funding varies. $77.3 \%$ of social science and humanities projects receive external funding, but only $50 \%$ of cultural science and humanities projects do. In between are engineering and planning sciences $(69.2 \%)$, mathematics and computer science $(66.7 \%)$, and natural sciences $(63.4 \%)$.

\subsubsection{Overarching Project Goals}

When asked about the overarching project goals, "answering scientific research questions" was selected by thirty-six projects (46.2\%) as the most important goal, thirteen projects named it as the second most important goal $(16.6 \%)$, and another seven projects named it as the third most important goal $(8.9 \%$; see Figure 1$)$. This results in the first rank in the overall weighting. These are followed, but already at a clear distance, by "open science to society", "communicate scientific findings", and "promote understanding of science". These first four meta-goals can in turn be assigned to two core aspects of citizen science: creating knowledge and sharing knowledge.

\subsection{Researchers and Citizen Scientists in the Projects}

\subsubsection{Academic Staff}

How many employees currently work in how many positions within German citizen science projects? Table 1 gives an overview of the results. Sixty projects provided information on their academic staff, of which four projects stated that they had none. On average, the projects employ three researchers, but they share just over one position (full-time equivalent).

All seventy-nine projects provided information on the position of a volunteer coordinator. The question was formulated in such a way that both employees and volunteers could be named. Fifty-six of the projects did not explicitly assign this task. The majority have assigned it to one person, some to several (on average 0.8 persons). The situation is similar for the task of public relations, although only 41 projects provided information. Of these, 20 did not assign any person to the task, with an average of 0.8 persons.

In view of the figures just presented, it is not surprising that the assessment of staffing in the project is critical overall. Sixty-nine projects made statements on this, 41 projects $(52.6 \%)$ chose "inadequate for the number of tasks", and 28 projects $(35.9 \%)$ rated the situation as "adequate". 


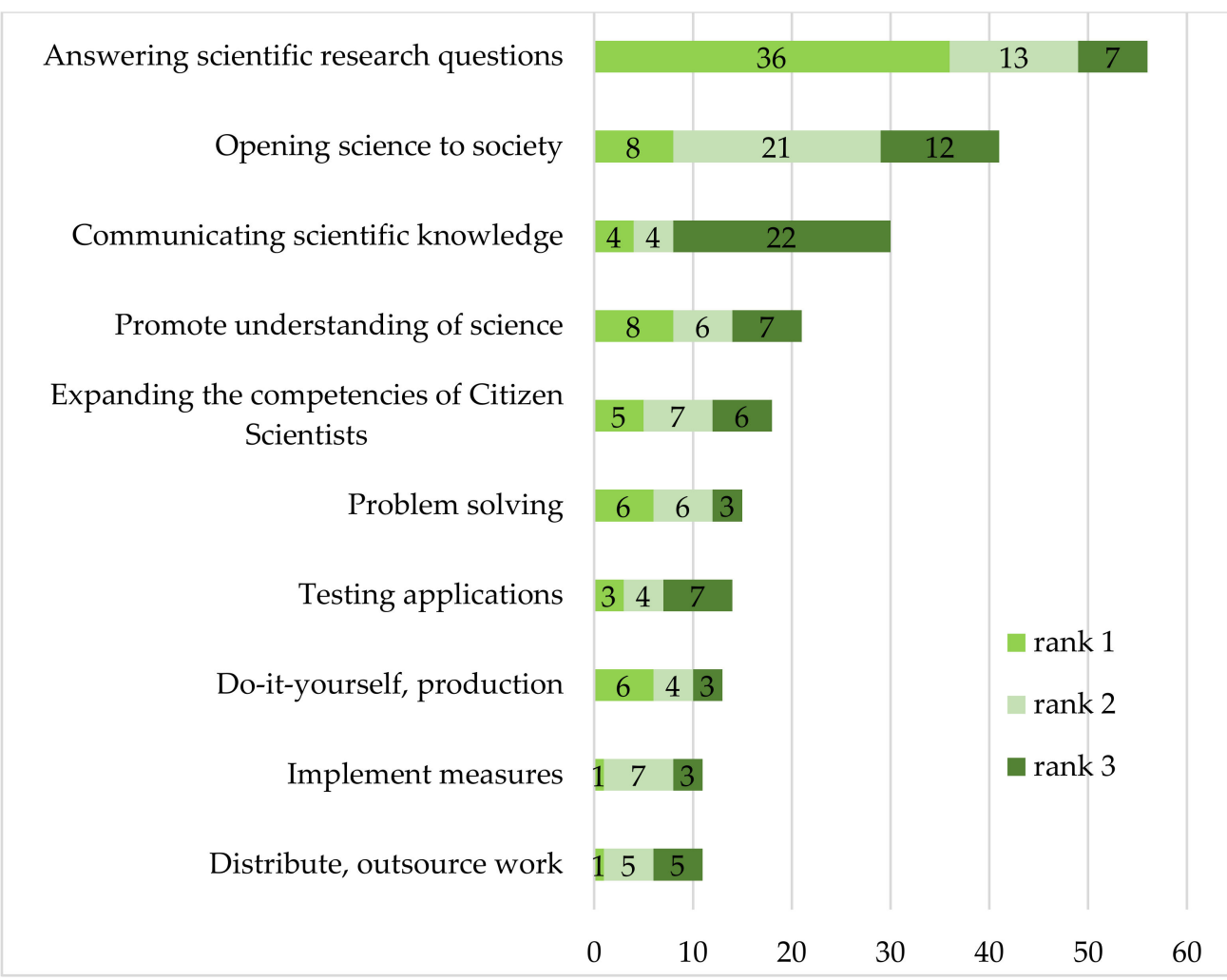

Figure 1. Overarching project goals. $N=78$. Quantities of rankings.

Table 1. Staff in the projects ${ }^{1}$.

\begin{tabular}{|c|c|c|c|c|c|c|c|c|c|c|c|c|}
\hline & \multicolumn{8}{|c|}{ Quantity of Persons } & \multicolumn{4}{|c|}{$\begin{array}{l}\text { Full-Time } \\
\text { Positions }\end{array}$} \\
\hline & $n$ & $\mathbf{0}$ & 1 & 2 & 3 & 4 & $\operatorname{Max}$ & Mean & Do Not Know & Mean & (SD) & Do Not Know \\
\hline Researchers & 60 & 4 & 19 & 17 & 10 & 2 & 30 & 3.0 & 3 & 1.04 & 0.19 & 11 \\
\hline $\begin{array}{l}\text { Volunteer } \\
\text { coordinator }\end{array}$ & 79 & 56 & 15 & 4 & 1 & 0 & 25 & 0.8 & 4 & 0.18 & 0.31 & 7 \\
\hline $\begin{array}{l}\text { Public } \\
\text { relations }\end{array}$ & 41 & 20 & 16 & 1 & 3 & 0 & 6 & 0.8 & 4 & 0.18 & 0.33 & 8 \\
\hline
\end{tabular}

${ }^{1} N=41-79$. Number of persons, max, and mean value of persons. Number, mean value, and standard deviation of full-time positions.

\subsubsection{Citizen Scientists}

In an open response format, the number of participating citizen scientists could be provided for the year 2019. Sixty-five projects answered the question. Taken together, they documented the participation of 63,339 citizen scientists in total. The range of numbers varied from two to 30,000 people (see Table 2 and Appendix A Table A2). Fifty projects $(77 \%)$ reported up to 300 participants.

Table 2. Number of participating citizen scientists in 2019 in 78 responding projects.

\begin{tabular}{ccccccc}
\hline & $\boldsymbol{n}$ & Mean & SD & Min & Max & Sum \\
\hline Quantity citizen scientists in 2019 & 65 & 976.0 & 3861.9 & 2 & 30,000 & 63,439 \\
"short-term" & 49 & 230.5 & 476.3 & 3 & 3000 & \\
"medium-term" & 45 & 104.5 & 243.6 & 1 & 1500 & \\
"long-term" & 49 & 105.1 & 361.1 & 1 & 2500 & \\
\hline
\end{tabular}

Projects could additionally specify whether their volunteers were "short" — (defined as once or for a very short time), "medium" - (defined as multiple participation but rather infrequently or irregularly), and/or "long"-term (defined as more often and/or regular 
participation) in terms of the length of their activity. Between 45 and 49 projects answered these questions. Here, too, the range was wide.

These figures do not yet say anything about whether the projects succeed in recruiting the necessary number of citizen scientists for their tasks. Therefore, an assessment in three categories was requested for the years 2019 (i.e., retrospectively) and 2020 (prospectively, with reference to the consideration of possible limitations due to the Corona pandemic). If the two assessments on overall participation (marked as "all" in Table 3) are compared, there are hardly any differences. For 2019 and 2020, 15.4\% of projects rated participation as "lower than expected/needed", and $16.7 \%$ and $17.9 \%$, respectively, rated it as "higher than expected/needed". Participation was as expected for 50\% of projects in 2019 and for $35.9 \%$ in 2020. We found that for 2020,14.1\% selected the option "I do not know", meaning that they were not yet able to give any concrete assessments at the time of the survey.

Table 3. Rating of participating citizen scientists in 2019 and 2020 in percent in 78 responding projects.

\begin{tabular}{ccccc}
\hline $\begin{array}{c}\text { Number in 2019 } \\
\text { (Retrospection) }\end{array}$ & $\begin{array}{c}\text { Less than } \\
\text { Expected/ } \\
\text { Necessary }\end{array}$ & $\begin{array}{c}\text { As } \\
\text { Expected/ } \\
\text { Necessary }\end{array}$ & $\begin{array}{c}\text { Greater than } \\
\text { Expected/Necessary }\end{array}$ & $\begin{array}{c}\text { Not } \\
\text { Answered }\end{array}$ \\
\hline all & 15.4 & 50.0 & 16.7 & 17.9 \\
"short term" & 12.8 & 42.3 & 10.3 & 34.6 \\
"medium" & 15.4 & 41.0 & 10.3 & 39.7 \\
"long" & 17.9 & 35.9 & & Do Not Know \\
\hline Number in 2020 & & & 17.9 & 14.1 \\
(Prospection) & & 35.9 & 7.7 & 14.1 \\
\hline "short term" & 15.4 & 33.3 & 3.8 & 15.4 \\
"medium" & 16.7 & 38.5 & 12.8 & 16.7 \\
\hline
\end{tabular}

4.2.3. Knowledge about Demographics and Characteristics of Citizen Science Participants in the Projects

We were interested in what information was collected about the citizen scientists involved in the projects. Figure 2 shows the total of 17 presented options. The projects selected between one and 14 options (on average 3.4). 61.5\% of the projects collected personal data, including contact details. This was followed, at a great distance, by the recording of satisfaction (for example, with the project, with participation, or with the results $(25.6 \%))$. Just under a quarter of the projects recorded age, gender, or place of residence $(25.6 \%, 24.4 \%$, and $24.4 \%$, respectively) and even fewer projects asked for affiliation to target groups (e.g., nationalities, ethnicities, income, or occupational groups, 14.1\%).

With reference to the relevant overarching project goals reported in the Section 4.1.3. it is interesting to see that practically no data are collected to somehow verify the objectives "Expanding the competencies of citizen scientists" and "Promoting the understanding of science". This could be information on prior knowledge in relation to the topics of the project $(14.1 \%)$, levels of education, knowledge gain (each $12.8 \%$ ), or competence levels $(10.3 \%)$, as well as "Expectations towards the project", "Attitudes, opinions on aspects relevant to the project" (each 15.4\%), "Experiences" (e.g., during implementation; 16.7\%), or "Motivations for participating in the project" (17.9\%).

\subsubsection{Levels of Participation Offered for Citizen Scientists}

Multiple answers were possible. Thirty-nine projects responded to offer one specific role. Twelve projects offered two different roles, fifteen projects three, seven projects four, three projects five, and two projects all six possible roles.

Almost all projects (91.0\%) work with their volunteers as "contributors", $44.9 \%$ were involved as "collaborators", and $30.8 \%$ as "co-creators". $20.5 \%$ of the volunteers were 
active as "colleagues" [4], and $12.8 \%$ of the volunteers were involved as "hosts", e.g., by providing rooms, material, or technology. Nine percent were "project leaders".

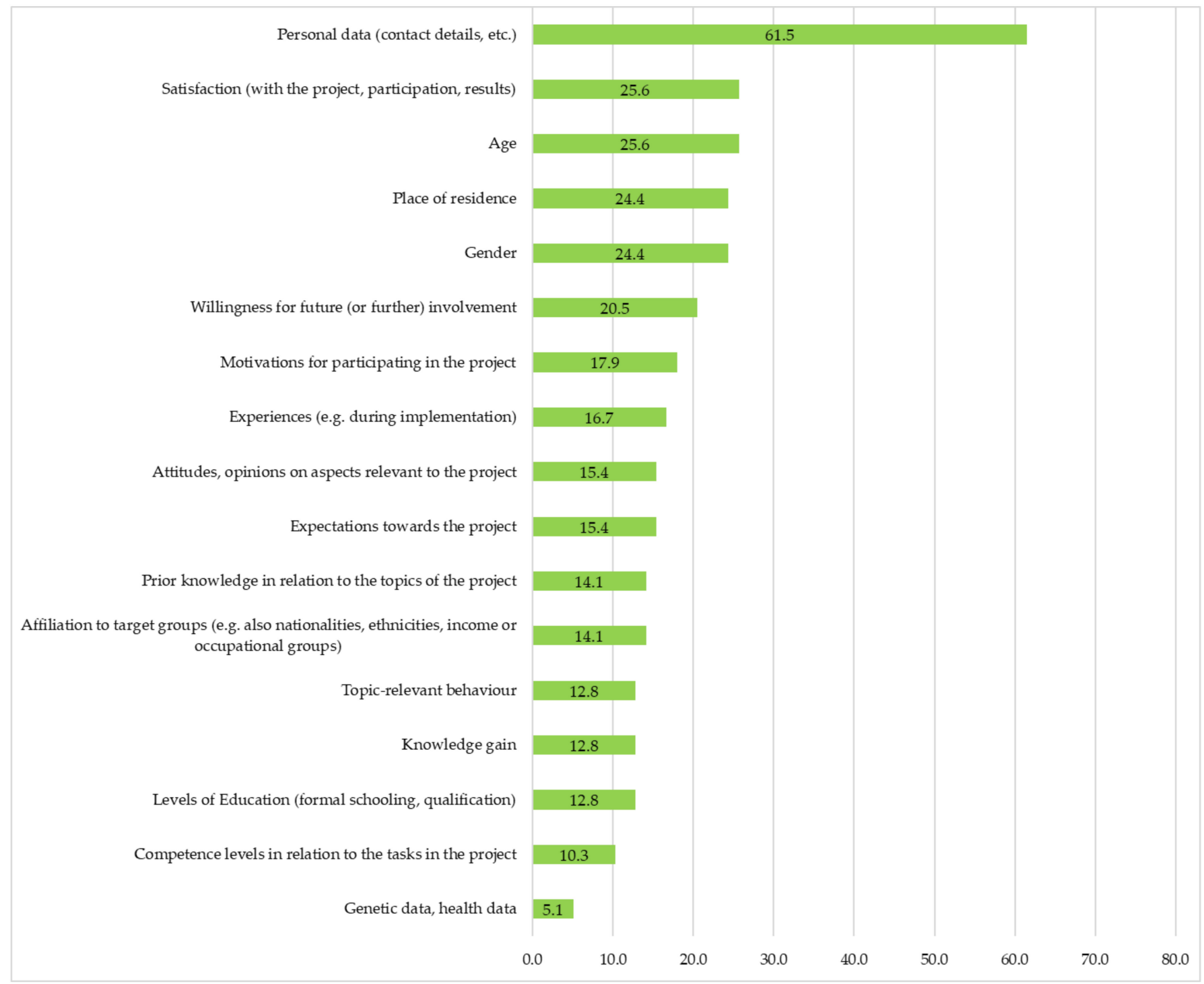

Figure 2. Knowledge about the citizen science participants in the projects. $N=78$. Percentages sorted in descending order.

\subsubsection{Organisation and Sharing of Various Scientific Tasks in the Projects}

With this question, it should be clarified whether specific tasks were handled by both academic researchers and citizen scientists or whether there was a clear division of activities. The presented tasks were only to be selected if the task was actually relevant in the project. In the first step of the analysis, we checked which activities were taken on by which group. According to this, the researchers took on $54.4 \%$ of the tasks alone, the citizen scientists $18.5 \%$, and in $23 \%$ both groups (26.9\%) shared the tasks (Figure 3 ).

The percentages indicate the respective distribution in the projects. The left section of the bars (in green) represents the tasks that are taken on by "both groups" (together or separately). Handling data takes the top positions here: discussing results (implemented in $47.4 \%$ of the projects); interpreting data (35.9\%); evaluating data (30.8\%); collecting measurement data (26.9\%); disseminating results (21.8\%); and "sorting, categorising, describing, indexing" data (21.8\%). In as many as one fifth of the projects, both groups $(20.5 \%)$ also carried out the quality check.

The middle section of the bars (in yellow) shows which tasks are carried out by the "citizen scientists (alone)". For the task "data collection", two different answer options 
were offered: observing (51.3\%) and measuring (37.2\%). In addition, the activity group "sorting, categorising, describing, indexing" (25.6\%) described a time-consuming analysis of already collected data. It is noticeable that citizen scientists predominantly carried out these three activities.

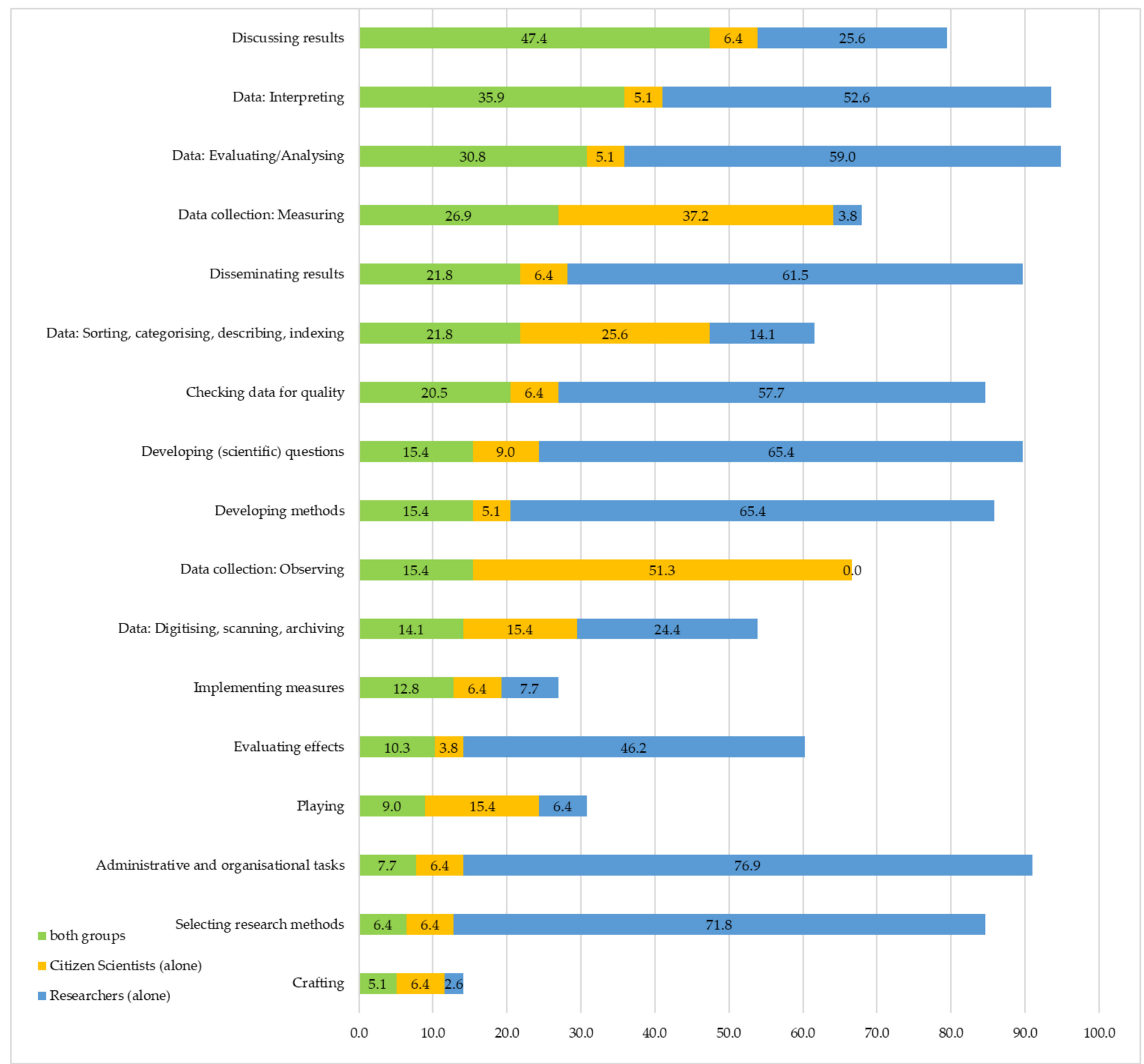

Figure 3. The organisation and allocation of various scientific tasks in the projects. $N=78$. The percentages indicate the respective distribution in the projects sorted in descending order according to the distribution in both groups (green bars), citizen alone (orange), or researchers alone (blue).

The right section of the bars (in blue) is reserved for the activities of the "researchers (alone)". According to the respondents, they take on the largest share of the work overall. In $71.8 \%$ of the projects, they exclusively do administrative and organisational tasks. The next most common tasks are closely related to research methodology: in $71.8 \%$ of the projects, the researchers are responsible for selecting the methods, as well as for developing the methods and the scientific questions (65.4\% in each case). Additionally, analysing data 
$(59.0 \%)$, interpreting data (52.6\%), disseminating results $(61.5 \%)$, and checking the quality of the data $(57.7 \%)$ are in the hands of the researchers in more than half of the projects.

\subsubsection{Degree of Autonomy}

The degree of autonomy of the citizen scientists was to be assessed with the help of various aspects in the work organisation. For this purpose, ten items were presented, five of which relate more to activities that give the volunteers a high degree of autonomy (in Figure 4) and another five that are more representative of the task-oriented approach of the projects. Multiple answers were possible.

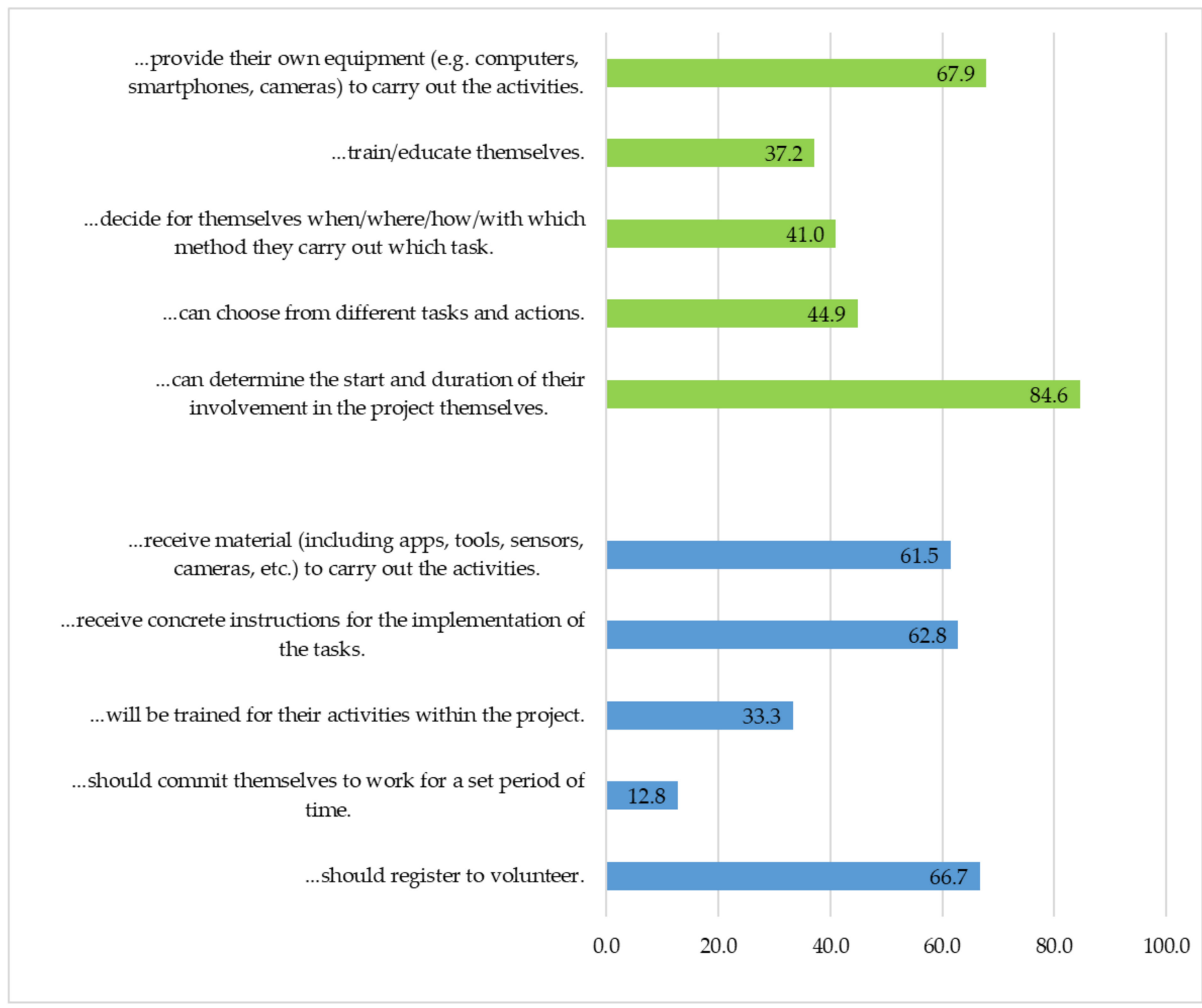

Figure 4. Assessing the degree of autonomy of the citizen scientists in the projects. $N=78$. Green bars show aspects that tend to speak for a high degree of autonomy, blue bars for a low level of autonomy.

The item "The citizen scientists ... can determine the start and duration of their involvement in the project themselves" received the highest level of agreement (84.6\%), and only $12.8 \%$ of the projects stated that citizen scientists should commit themselves to working for a fixed period of time if possible. Registration was desired by $66.7 \%$ of the projects.

$61.5 \%$ of the projects provided their volunteers with material or equipment to carry out the activities. In $67.9 \%$ of the projects, the volunteers (also) provide their private equipment such as computers, smartphones, or cameras. 
$44.9 \%$ of the projects offered their volunteers a choice of different tasks and activities. $41.0 \%$ (32) of the projects left it up to their volunteers to decide when, where, how, and with which method they carried out which tasks. $62.8 \%$ of the projects, on the other hand, gave their volunteers concrete instructions on how to carry out the tasks.

$37.2 \%$ of the projects stated that the volunteers train or educate themselves to carry out the tasks. $33.3 \%$ of the projects offered such training as part of the project.

For a further evaluation step, we divided the projects into two groups in order to examine the extent to which autonomy plays a role. We selected only agreement or disagreement with the item " ... to decide when, where, how and with which method they carry out which tasks" as a distinguishing criterion. Thirty two projects agreed (41\%), while 59\% (46) did not. We expected to find differences between these two groups, but all tests failed to reach significance. When socio-demographic data were collected (see also Section 4.2.3.), the mean for the selected options was 3.3 out of 17 (SD 3.76). In group 1 ("low autonomy"), the mean was 2.89 (SD 3.35), and in group 2 ("high autonomy"), the mean was 3.88 (SD 4.33; Welch $\mathrm{t}=-1.0798, \mathrm{df}=55.523, p$-value $=0.2849$, CI 95: $-2.808958-0.841567)$. This result contradicts our expectations; we would have assumed that the projects that follow the task-led approach and therefore grant their citizen scientists a low degree of autonomy would have required more information about their volunteers. There was also no difference in the project coordinators' satisfaction with the quality of the scientific results. In group 1 ("low autonomy"), the mean was 4.07 (out of $5=$ very satisfied; SD 0.79), and in group 2 ("high autonomy") it was 3.96 (SD 0.65; Welch $\mathrm{t}=0.60973$, $\mathrm{df}=63.142, p$-value $=0.5442$, CI 95: $-0.2396130-0.4500507)$.

\subsection{Research on the Impact of the Projects}

Forty-eight projects $(61.5 \%)$ reported that they conducted impactful research on specific project objectives with their own staff, while two projects $(2.6 \%)$ outsourced this to third parties. Twenty-three projects $(29.5 \%)$ did not carry out any impact research.

For the area of evaluated effects, there were three choices with multiple answer options. The "effect on participants" was researched by forty-three projects (43.6\%), an ecological evaluation (effect on biodiversity, plants, animals, habitats, etc.) was carried out by 13 projects $(16.7 \%)$, and an economic evaluation (economic effects of the project or cost-benefit analysis of individual measures) was carried out by five projects $(6.4 \%)$.

Projects responded to collect the majority of the research impact data through interviews, surveys, and knowledge tests (32.9\%), followed by interviews (22.8\%) and rarely through analyses of web statistics and before-and-after comparisons (each $15.2 \%$, see Figure 5). 


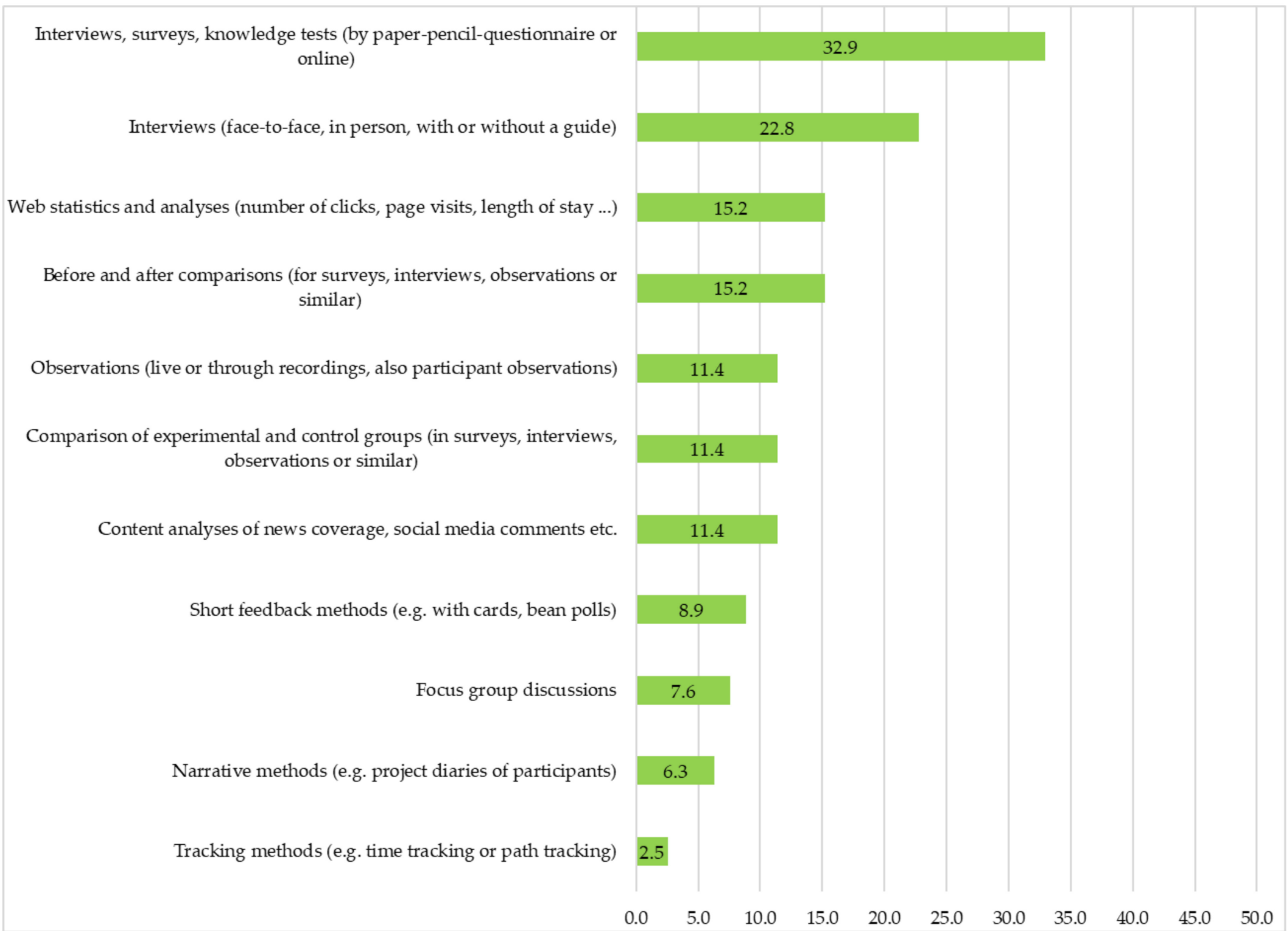

Figure 5. Survey methods used in impact research. $N=78$. Percentages sorted in descending order.

\section{Discussion}

Our study contributes to the understanding of the citizen science landscape in Germany based on data provided by 79 citizen science projects ( $56 \%$ of all projects) presented on the German citizen science platform in 2020. Due to the response rate, we explicitly do not aim to generalise our analyses to all citizen science projects in Germany. Our results provide good insight into the practice of the participating projects, but not beyond. In the following, we would like to discuss some aspects first on the basis of the results. Further on, we will present interpretations and possible explanations as well as challenges and ways forward based on our extensive experience in project consultation.

Like in the previous study by Pettibone et al. [24] on German citizen science platform projects in 2016, it is once more evident that the focus of most citizen science projects is still on the natural sciences. Due to different approaches to data collection, we cannot directly compare the data sets. Pettibone et al. had assigned only one discipline per project (which they assumed would result in a scientific publication during the course of the project). In our study, querying several possible disciplines proved to be very informative as many schemes work inter- or transdisciplinary. However, we also learned that we still have a lack of projects from disciplines such as cultural sciences, social sciences and humanities, engineering and planning, mathematics and computer science, economics, and law. The proportions of disciplines have hardly changed since 2016. However, we are aware that not all citizen science projects in Germany are presented on the national citizen science platform. One of the possible reasons is that not all disciplines identify with the term "citizen science" for their participatory research activities. We experience this especially in the field of historical research. In far more than 600 associations in Germany (own 
estimate, e.g., [48]), participatory as well as autonomous research is conducted on regional studies, local dialects, historical personalities and events, architectural and soil monuments, landscape use, crafts, and many other topics.

Two thirds of the projects were initiated by research institutions, universities, or colleges, and one third by associations, interest groups, NGOs or foundations, public authorities, or private persons. Slightly more than one third work were without external funding, and almost two thirds received funding from various sources. The funding was closely related to staffing, and we were surprised to learn that while on average three researchers per project were employed, they shared a total of just over one post (full-time equivalent). This means that many researchers only had a part-time position, which was probably also limited to the project duration. Slightly more than half of the projects dis not have a limited duration, but one-third lasted between one and four years, some longer. Accordingly, half of the respondents rated the staffing situation as inadequate for the number of tasks.

Two of the challenges we would like to highlight are: first, we have learned that as few as 78 project coordinators (on average, only one academic employee per project) organised and coordinated the participation of 63,339 citizen scientists in 2019. Second, the same researchers needed to fulfil key project objectives, namely, to answer scientific research questions while promoting scientific literacy among volunteers and disseminating science to society. This bundle of requirements for citizen science projects or their coordinators has already been described many times, e.g., [49-51], and critically discussed with regard to a possible overloading of the projects [51]. Our findings match those of other researchers like Sorensen et al. [49] (p. 6), who cited a project leader from the Baltimore Mosquito Study: "The funding and publication demands of inter/transdisciplinary research do not match those of federal granting or university level expectations both in terms of time, resources, and with respect to project ownership".

Since participating in research has a very long history in Germany for volunteers and citizen science has been well established for about fifteen years [14-19,23-25], we, the authors, were partly surprised that the projects recorded very little information about their volunteers in a systematic way. About two-third of the projects asked for a registration and therefore had contact data of their project participants. Very little is known about any other socio-demographic information or other characteristics that would allow for conclusions to be drawn about the diversity, representativeness, and inclusiveness of the study regarding the participants. To the best of our knowledge, the majority do not ask in advance what roles are accepted, what prior knowledge or skills citizens bring with them, or want they want to learn. This is why we call them "The Known Unknowns".

\subsection{Lack of Accompanying Research and Representative Studies}

We state an overall lack of data on diversity and inclusiveness in German citizen science projects, and especially on the level of the citizen science projects a lack of methodological knowledge and of data protection issues. Our survey revealed that only two third of the projects conduct accompanying research, but only with a very limited focus on content. There seems to be also uncertainty about appropriate methods for collecting information on diversity.

This is true even for projects that explicitly address specific target groups. Here is an example from one of our project partners who is already sensitive to the question and seeking guidance: "We are in the planning stage of a project that will focus on the representation and reception of history. We explicitly want to reach the greatest possible diversity of participants. However, how can we sensitively query diversity criteria? Is it even possible? Doesn't this repel people who do not want to be reduced to their diversity aspects? How do we deal with the information, what do we do with it? It is still unclear to us how this will be implemented in practice." In addition, the General Data Protection Regulation (GDPR, [52]) places very high demands on the storage of personal data, which not all projects can ensure. To help educate people on the correct handling of this sensitive 
data, the Museum für Naturkunde published a guide in 2020 [53]. In this, we recommend that all personal data be collected as sparingly as possible. In addition, two different working groups were established in 2021 in cooperation with "Bürger schaffen Wissen", with regular open meetings, collegial consultations, and free training programs.

Some of the possible reasons discussed above can be circumvented by collecting information on participant structures through external monitoring research and evaluations in anonymous form, often through online surveys. The advantages are the professional use of standardised methods and a neutral and external consultant perspective. However, we see two main difficulties: the representativeness and the time factor. Even though response rates in accompanying research seem to be quite high overall [19,26-28], these data represent self-selected samples and provide only a limited picture of the diversity of the participants. The data support the image of male and well-educated participants.

However, perhaps these only represent those who are willing to participate in the accompanying studies in addition to their voluntary work? The question of who participates in accompanying research was debated by Moczek [27] on the citizen science project "Insects of Saxony". During a focus group discussion with about sixty citizen scientists, about half of the participants confessed that they "never take part in surveys as a matter of principle". A few of the participants explicitly regretted this in retrospect, as the presentation and discussion of the findings had shown them how trustworthy and valuable such studies can be for the project coordinators and also their own engagement. It is also conceivable that people tend to take part in such a survey who were more likely to be driven by pro-social motivations [27].

All of this can lead to a bias in the respondent pool and therefore also in the results. It is likely that they do not represent the entirety of the participants. And even with projectaccompanying formative evaluations, the results are only available with a certain delay. Subsequent adjustments in the course of the project, for example, in addressing specific target groups, may therefore also be delayed. This could cause major problems for projects with a short duration.

One essential approach to answering these fundamental questions on participating is to conduct nationwide, representative studies, such as the presented German Volunteer Surveys [21,22] or the ones from Great Britain [5] and Switzerland [29].

\subsection{Particularities of the Trustful Cooperation between Academic Researchers and Citizen Scientists}

Against the backdrop of the often strongly limiting organisational framework conditions for many projects, it is a great challenge to recruit and retain volunteers, e.g., [35,36]. In order to get started and find participants, projects often approach existing groups (such as associations and civil organisations) that already have a connection or interest in the issue for pragmatic reasons. This is where the likelihood of participation is considered to be the highest. This results in a selection bias that must be compensated for by further studies if the diversity of participants should be increased.

About one third of the projects we surveyed are coordinated by either an NGO, civic organisation, or foundation. When working with volunteers, their offer to participate in research is often designed specifically for their members, even though practically all of them are open to other volunteers. In this relationship of trust, which has often grown over many years, e.g., $[17,19]$, it would be inconceivable to systematically collect and store information on, for example, ethnicity, socio-economic and sociocultural status, educational status, or socio-political attitudes before taking up a volunteer activity; this could discourage potential participants from taking part.

Almost all projects offer their volunteers the role of "contributor" [4]. Nevertheless, we also see that almost half of the projects make specific offers of participation at different levels and at all stages of the project or let the volunteers themselves define them in cocreation processes. This matches well with the findings of an European survey, were Hecker et al. stated that half of the estimated 1.2 million participants in 174 European citizen science 
projects primarily collect data, and an additional 27 per cent are also involved in project design and data analysis [54].

The project coordinators in our survey are, in most of the projects, responsible for the coordination of the project overall, especially for administrative and organisational tasks, as well as for deriving the scientific questions, developing the methods, checking the quality of the data, analysing and interpreting data, and disseminating results. In summary, they take over alone more than half of the work to be done, but they get massive help by the volunteers. The citizen scientists perform just under one fifth of the tasks alone, predominantly in the area of data collection, and in a further just under one quarter of the tasks these were performed jointly (or separately) by both groups of actors. Additionally, the volunteers not only contribute their working time and skills but apparently also provide equipment and material to a considerable extent. In almost two-third of the surveyed projects, the possible tasks and requirements are described precisely, increasingly also for different interests and competence levels of the citizen scientists. One-third of the schemes offered special trainings for the volunteers. The dissemination of these "task descriptions" takes place through various channels, with a very important role being played by the presentation on the citizen science platform and volunteer portals.

In contrast to filling a position in an employment relationship, however, there is usually no systematic selection process. This is backed by the overall low level of information that projects gather about their volunteers. This process is also related to the limited permanent employees. To the best of our knowledge, the matching with the activities or predefined target groups is not checked on the basis of facts (such as certificates, attestations, or other evidence) nor for the projects with high nor low autonomy but is usually based on the volunteers' self-assessment and thus presupposes a high level of trust between the parties involved. As already discussed above, we would like to emphasize again the special function of "informed trust" in this particular kind of social relationship and research collaboration, which has been debated recently [55-57]. Next to trust, we consider experiencing autonomy and competence to be the three most important driving factors for contributing to a citizen science project $[19,34,37,57]$.

\section{Conclusions}

Our findings illustrate the complexity of research on participant diversity in practice, identifying dilemmas that arise from the tensions between the aspirations and hopes associated with citizen science and the pragmatic and procedural realities of "science of citizen science" research in practice.

We must note with regret, but also with understanding, that, overall, we know very little about citizen scientists, so that we cannot make any reliable statements about diversity and representativeness in German projects. Any attempt to infer the totality from the incomplete information must inevitably lead to misjudgements in one direction or the other. We must further note that we still know much less about the other stakeholders in citizen science projects, such as the academic researchers and the enablers $[57,58]$.

We highly recommend that citizen science projects actively engage with these issues and that they need to develop individual strategies to (further) increase the diversity [7,31]. This will also lead to a broader dissemination and added benefit of these collaborations: the transference of program impacts to individuals outside of the program as highlighted by Lynch-O'Brian et al. [59].

However, we would also argue that the task of accompanying research and evaluation [60] cannot be borne by the projects alone. It needs a national, overarching strategy and funding is particularly important for representative, cross-sectional, e.g., [5,29] and long-term, studies [21,22].

However, we would like to express the notion that, as science opens up, the willingness of citizens to participate in accompanying research may decrease further. If citizens experience that they are emancipating themselves from being a science object to becoming a self-determined participant [2,3], they may increasingly want to question accompanying 
research. Experimental studies that turn respondents back into mere objects and leave them in the dark as to what the real research questions are will possibly be rejected. However,, if participants are fully informed about the underlying research questions, reactive selfreport changes and Hawthorne-effects could become more apparent [61] and may undermine the construct validity [62] (pp. 100-101). In any case, the classical experimental studies with repeated measures for testing change hypotheses will hardly be possible in this context [62] (p. 728ff).

This also could further increase multiple self-selections in the future and thus prevent a valid answer to the true diversity of the participants. Crucial dynamics of change could also arise from the further increase in digitalisation. Digital communication facilitates networking as well as public presentation, including of research outside professional science. Finally, the means available to citizen scientists are expanding through the use and further development of open source-based software and hardware, e.g., [40]. This can thus lead to a new science "from below" that links excluded practices of citizen science with the trend towards open science and open source, e.g., [50,63]. Yet, the increase in digital communication and participation could also lead to personal contact between the different actors becoming rarer and retreating to an at least partially anonymised form. This could also obscure knowledge about the true identities and characteristics of the participants or their diversity in the future.

The answer to this dilemma can therefore not only be the simple demand for quantitatively more systemic accompanying research. Particularly for researching the structure, diversity, and extent of participation in Citizen Science projects, co-creative and qualitative approaches are also suitable, and we would like to see more use of these methods.

Author Contributions: Conceptualisation, N.M. and S.L.V.-H.; methodology, N.M.; software, N.M. using SoSciSurvey.com; validation, formal analysis, data curation, N.M.; writing-original draft preparation, N.M.; writing — review and editing, N.M., S.H. and S.L.V.-H.; visualisation, N.M.; project administration, S.L.V.-H. All authors have read and agreed to the published version of the manuscript.

Funding: The survey was funded by the German Federal Ministry of Education and Research (BMBF; 01BF1901A). The publication was funded by the Open Access Fund of the Leibniz Association.

Institutional Review Board Statement: Ethical review and approval were not required for this study as we worked closely with the data protection officer to provide all participants with detailed information about the conditions. Only after agreeing to these could they participate in the survey. Specifically, we informed participants that participation was voluntary, questions could be skipped, and participation in the study could be terminated at any time and information already stored could be completely deleted. Publication of the results does not allow for any conclusions to be drawn about the project or the individual. The data were stored in a database of the Museum für Naturkunde Berlin exclusively for research purposes. The survey software SoSciSurvey was developed and is operated by a German company. The server is located in Munich, Germany. All privacy settings were set restrictively.

Informed Consent Statement: Informed consent was obtained from all subjects involved in the study.

Data Availability Statement: The data presented in this study are available on request from the corresponding author. The data are not publicly available due to only an excerpt of the data being presented in this article and further publications planned.

Acknowledgments: The authors like to thank all participating citizen science projects for so willingly providing information and facts. We also sincerely thank our colleagues at Museum für Naturkunde Berlin and our partners at Wissenschaft im Dialog, Wiebke Brink, Florence Mühlenbein, and Julia Lorke, especially during the phase of developing the survey content. For complementary discussions on the recruitment and selection process, we sincerely thank Dorte Riemenschneider, Kristin Oswald, Agnes Grützner, Denise Meyer, and Ralf Baumgarth.

Conflicts of Interest: The authors declare no conflict of interest. The funders had no role in the collection, analyses, or interpretation of data; in the writing of the manuscript; or in the decision to publish the results. 


\section{Appendix A}

Table A1. Categorised disciplines.

\begin{tabular}{|c|c|c|c|}
\hline Discipline & Frequencies & Percent & Category \\
\hline Biology: Biodiversity & 27 & 34.6 & Natural Science \\
\hline Biology: Zoology & 17 & 21.8 & Natural Science \\
\hline Environmental Sciences & 17 & 21.8 & Natural Science \\
\hline Geography & 13 & 16.7 & Natural Science \\
\hline Computer Science & 9 & 11.5 & $\begin{array}{l}\text { Mathematics and } \\
\text { Computer Science }\end{array}$ \\
\hline Biology: Botany & 8 & 10.3 & Natural Science \\
\hline History & 7 & 9.0 & $\begin{array}{l}\text { Cultural Studies and } \\
\text { Humanities }\end{array}$ \\
\hline Biology & 7 & 9.0 & Natural Science \\
\hline Medicine and Health Sciences & 7 & 9.0 & Social and Human Sciences \\
\hline $\begin{array}{c}\text { Pedagogy and } \\
\text { Educational Sciences }\end{array}$ & 7 & 9.0 & Social and Human Sciences \\
\hline Information Sciences & 5 & 6.4 & $\begin{array}{l}\text { Engineering and } \\
\text { Planning Sciences }\end{array}$ \\
\hline Biology: Oceanography & 5 & 6.4 & Natural Science \\
\hline Cultural Sciences & 4 & 5.1 & $\begin{array}{c}\text { Cultural Studies and } \\
\text { Humanities }\end{array}$ \\
\hline Physics & 4 & 5.1 & Natural Science \\
\hline Sociology & 4 & 5.1 & Social and Human Sciences \\
\hline $\begin{array}{l}\text { Architecture and } \\
\text { Urban Planning }\end{array}$ & 3 & 3.8 & $\begin{array}{l}\text { Engineering and } \\
\text { Planning Sciences }\end{array}$ \\
\hline Engineering & 3 & 3.8 & $\begin{array}{l}\text { Engineering and } \\
\text { Planning Sciences }\end{array}$ \\
\hline $\begin{array}{c}\text { Genealogy } \\
\text { (Genealogical Research) }\end{array}$ & 3 & 3.8 & $\begin{array}{l}\text { Cultural Studies and } \\
\text { Humanities }\end{array}$ \\
\hline $\begin{array}{c}\text { Media and } \\
\text { Communication Sciences }\end{array}$ & 3 & 3.8 & $\begin{array}{c}\text { Cultural Studies and } \\
\text { Humanities }\end{array}$ \\
\hline $\begin{array}{c}\text { Agricultural and } \\
\text { Veterinary Sciences }\end{array}$ & 3 & 3.8 & Natural Science \\
\hline Meteorology & 3 & 3.8 & Natural Science \\
\hline Action Research & 3 & 3.8 & Social and Human Sciences \\
\hline Design Research & 2 & 2.6 & $\begin{array}{l}\text { Engineering and } \\
\text { Planning Sciences }\end{array}$ \\
\hline Archaeology & 2 & 2.6 & $\begin{array}{c}\text { Cultural Studies and } \\
\text { Humanities }\end{array}$ \\
\hline Art (Painting, Performing Arts, Music, etc.) & 2 & 2.6 & $\begin{array}{l}\text { Cultural Studies and } \\
\text { Humanities }\end{array}$ \\
\hline Astronomy & 2 & 2.6 & Natural Science \\
\hline Chemistry & 2 & 2.6 & Natural Science \\
\hline History of Art & 1 & 1.3 & $\begin{array}{l}\text { Cultural Studies and } \\
\text { Humanities }\end{array}$ \\
\hline Literature & 1 & 1.3 & $\begin{array}{l}\text { Cultural Studies and } \\
\text { Humanities }\end{array}$ \\
\hline Linguistics & 1 & 1.3 & $\begin{array}{l}\text { Cultural Studies and } \\
\text { Humanities }\end{array}$ \\
\hline $\begin{array}{c}\text { Biology: } \\
\text { Microbiology, Cell Biology }\end{array}$ & 1 & 1.3 & Natural Science \\
\hline Biology: Phenology & 1 & 1.3 & Natural Science \\
\hline Biology: Fungi & 1 & 1.3 & Natural science \\
\hline Geology & 1 & 1.3 & Natural Science \\
\hline Psychology & 1 & 1.3 & Social and Human Sciences \\
\hline Philosophy and Ethics & 0 & 0.0 & $\begin{array}{c}\text { Cultural Studies and } \\
\text { Humanities }\end{array}$ \\
\hline Political Science & 0 & 0.0 & $\begin{array}{c}\text { Cultural Studies and } \\
\text { Humanities }\end{array}$ \\
\hline
\end{tabular}


Table A1. Cont.

\begin{tabular}{cccc}
\hline Discipline & Frequencies & Percent & Category \\
\hline Theology & 0 & 0.0 & Cultural Studies and \\
Humanities & Mathematics and \\
Computer Science & Mathematics and \\
Logic & 0 & 0.0 & Computer Science \\
& & & Natural Sciences \\
Lathematics & 0 & 0.0 & Law \\
Anthropology & 0 & 0.0 & Economics \\
Law & 0 & 0.0 & Economics \\
Business Administration & 0 & 0.0 & 230.8 \\
\hline
\end{tabular}

Table A2. Number of participating citizen scientists in 2019.

\begin{tabular}{ccc}
\hline $\begin{array}{c}\text { Number of Participating Citizen } \\
\text { Scientists in 2019 } \\
\text { (Subsequently } \\
\text { Categorised) }\end{array}$ & Frequencies & \\
\hline$<10$ & & \\
10 & 6 & \\
$12-15$ & 4 & \\
30 & 3 & \\
50 & 3 & \\
60 & 5 & \\
$72-89$ & 2 & \\
$100-105$ & 3 & \\
150 & 8 \\
200 & 4 \\
$250-300$ & 3 \\
$304-338$ & 9 \\
500 & 3 \\
650 & 4 \\
800 & 1 \\
1000 & 1 \\
1755 & 3 \\
2515 & 1 \\
3400 & 1 \\
5000 & 1 \\
8000 & 1 \\
30,000 & 1 \\
\hline
\end{tabular}

\section{References}

1. ECSA (European Citizen Science Association). Ten Principles of Citizen Science. Available online: https://ecsa.citizen-science. net/wp-content/uploads/2021/05/ECSATenPrinciplesofCSEnglish.pdf (accessed on 17 July 2021).

2. ECSA (European Citizen Science Association). ECSA's Characteristics of Citizen Science. Available online: https://ecsa.citizenscience.net/wp-content/uploads/2020/05/ecsa_characteristics_of_citizen_science_-_v1_final.pdf (accessed on 17 July 2021).

3. Haklay, M.; Fraisl, D.; Tzovaras, B.G.; Hecker, S.; Gold, M.; Hager, G.; Ceccaroni, L.; Kieslinger, B.; When, U.; Woods, S.; et al. Contours of citizen science: A vignette study. R. Soc. Open Sci. 2021, 8, 339. [CrossRef]

4. Shirk, J.L.; Ballard, H.L.; Wilderman, C.C.; Phillips, T.; Wiggins, A.; Jordan, R.; McCallie, E.; Minarchek, M.; Lewenstein, B.V.; Krasny, M.E.; et al. Public participation in scientific research: A framework for deliberate design. Ecol. Soc. 2012, 17, 29. [CrossRef]

5. Pateman, R.; Dyke, A.; West, S. The Diversity of Participants in Environmental Citizen Science. CSTP 2021, 6, 9. [CrossRef]

6. Hermoso, M.I.; Martin, V.Y.; Stotz, W.; Gelcich, S.; Thiel, M. How Does the Diversity of Divers Affect the Design of Citizen Science Projects? Front. Mar. Sci. 2019, 6, 239. [CrossRef]

7. Cooper, C.B.; Hawn, C.L.; Larson, L.R.; Parrish, J.K.; Bowser, G.; Cavalier, D.; Dunn, R.R.; (Muki) Haklay, M.; Gupta, K.K.; Jelks, N.O.; et al. Inclusion in Citizen Science: The Conundrum of Rebranding. Science 2021, 372, 1386-1388. [CrossRef] 
8. United Nations Sustainable Development Group. Principle Two: Leave No One Behind. Available online: https:/ /unsdg.un.org/ 2030-agenda/universal-values/leave-no-one-behind (accessed on 26 July 2021).

9. European Commission. A Sustainable Europe Must Leave No One behind. Available online: https://www.eesc.europa.eu/en/ news-media/news/sustainable-europe-must-leave-no-one-behind (accessed on 26 July 2021).

10. Przibilla, B.; Linderkamp, F.; Krämer, P. Subjektive Definitionen von Lehrkräften zu Inklusion-Eine explorative Studie. [Subjective theories of inclusive education—an exploratory study]. Emp. Sonderpäd. 2018, 3, 232-247.

11. ECSA (European Citizen Science Association). Diversity and Inclusiveness. Available online: https://ecsa.citizen-science.net/20 21/01/12/diversity-and-inclusiveness-webinar-1-examining-how-dominant-white-culture-manifests-in-citizen-communityscience/ (accessed on 27 September 2021).

12. Bonn, A.; Brink, W.; Hecker, S.; Herrmann, T.M.; Liedtke, C.; Premke-Kraus, M.; Voigt-Heucke, S.; von Gönner, J.; Altmann, C.S.; Bauhus, W.; et al. Weißbuch Citizen Science Strategie 2030 Für Deutschland; preprint; 2021. Available online: https: / / doi.org/10.31235/osf.io/ew4uk (accessed on 15 October 2021). [CrossRef]

13. Paleco, C.; García Peter, S.; Salas Seoane, N.; Kaufmann, J.; Argyri, P. Inclusiveness and Diversity in Citizen Science. In The Science of Citizen Science; Vohland, K., Land-Zandstra, A., Ceccaroni, L., Lemmens, R., Perelló, J., Ponti, M., Samson, R., Wagenknecht, K., Eds.; Springer International Publishing: Cham, Switzerland, 2021; pp. 261-281. [CrossRef]

14. Blick, T. Mitwirkung von ehrenamtlichen ExpertInnen bei der Erfassung und Bewertung von Arten und Biotopen. In Kurzfassungen von Referaten. 28. Deutscher Naturschutztag 2006. Von lokalem Handeln und globaler Verantwortung-100 Jahre staatlicher Naturschutz, Bonn. 2006. Available online: http:/ /www.callistus.de/pdf_theo/Blick_vsn27_DNTBonn2006.pdf (accessed on 17 July 2021).

15. Daum, A. Wissenschaftspopularisierung im 19. Jahrhundert. Bürgerliche Kultur, Naturwissenschaftliche Bildung und Die Deutsche Öffentlichkeit, 1848-1914, 2nd ed.; Oldenbourg: München, Germany, 2002.

16. Leh, A. Die ehrenamtlichen Wurzeln des staatlichen Naturschutzes in Deutschland. In Freiwilligenarbeit im Naturschutz; Bremer, S., Erdmann, K.-H., Hopf, T., Eds.; Landwirtschaftsverlag: Münster, Germany, 2006; Volume 37, pp. 13-23.

17. Frohn, H.-W. Voluntary Nature Conservation through the Ages: Where do We Come From, and und Where are We Today? Mitt. POLLICHIA 2020. Volume 100, pp. 17-25. Available online: https://www.zobodat.at/pdf/Mitt-Pollichia_100_0017-0025.pdf (accessed on 26 July 2021).

18. Frohn, H.-W.; Rosebrock, J. (Eds.) Ehrenamtliche Kartierungen für den Naturschutz. Historische Analysen, aktuelle Situation und Zukunftspotenziale; Naturschutz und Biologische Vielfalt, Bd. 123; Bundesamt für Naturschutz: Bonn, Germany, 2012; ISBN 978-3-7843-4023-4.

19. Moczek, N. Freiwilliges Engagement für Citizen Science-Projekte im Naturschutz: Konstruktion und Validierung Eines Skalensystems Zur Messung Motivationaler und Organisationaler Funktionen. [Voluntary Engagement in Citizen Science Projects for Nature Conservation. Construction and Validation of a Scale System to Measure Motivational and Organisational Functions]; Pabst Science Publishers: Lengerich, Germany, 2019.

20. Bundesministerium für Umwelt, Naturschutz und Reaktorsicherheit (BMUB). [Federal Ministry for the Environment, Nature Conservation, Building and Nuclear Safety]. Nationale Strategie zur biologischen Vielfalt. Kabinettsbeschluss vom 7. November 2007. Berlin, Germany, 2007. Available online: http:/ / www.biologischevielfalt.de/fileadmin/NBS/documents/broschuere_ biolog_vielfalt_strategie_bf.pdf (accessed on 17 July 2021).

21. Simonson, J.; Vogel, C.; Tesch-Römer, C. (Eds.) Freiwilliges Engagement in Deutschland: Der Deutsche Freiwilligensurvey 2014. Available online: https://www.dza.de/fileadmin/dza/Dokumente/Forschung/Publikationen\%20Forschung/Freiwilliges_ Engagement_in_Deutschland_-_der_Deutsche_Freiwilligensurvey_2019.pdf (accessed on 26 July 2021).

22. Simonson, J.; Kelle, N.; Kausmann, C.; Tesch-Römer, C. (Eds.) Freiwilliges Engagement in Deutschland: Der Deutsche Freiwilligensurvey 2019; Deutsches Zentrum für Altersfragen: Berlin, Germany, 2021; Available online: https://www.bmfsfj.de/bmfsfj/service/ publikationen/freiwilliges-engagement-in-deutschland-176834 (accessed on 30 July 2021).

23. Liu, H.-Y.; Dörler, D.; Heigl, F.; Grossberndt, S. Citizen Science Platforms. In The Science of Citizen Science; Vohland, K., LandZandstra, A., Ceccaroni, L., Lemmens, R., Perelló, J., Ponti, M., Samson, R., Wagenknecht, K., Eds.; Springer International Publishing: Cham, Germany, 2021; pp. 439-459. [CrossRef]

24. Pettibone, L.; Vohland, K.; Ziegler, D. Understanding the (Inter) Disciplinary and Institutional Diversity of Citizen Science: A Survey of Current Practice in Germany and Austria. PLoS ONE 2017, 12, e0178778. [CrossRef] [PubMed]

25. Richter, A.; Dörler, D.; Hecker, S.; Heigl, F.; Pettibone, L.; Serrano, F.; Vohland, K. Capacity building in citizen science. In Citizen Science e Innovation in Open Science, Society and Policy; UCL Press: London, UK, 2018; pp. 269-283. [CrossRef]

26. Heym, E.C.; Schröder, J.; Kampen, H.; Walther, D. The Nuisance Mosquito Anopheles Plumbeus (Stephens, 1828) in Germany-A Questionnaire Survey May Help Support Surveillance and Control. Front. Public Health 2017, 5, 278. [CrossRef] [PubMed]

27. Moczek, N.; Nuss, M.; Köhler, J.K. Volunteering in the Citizen Science Project "Insects of Saxony"-The Larger the Island of Knowledge, the Longer the Bank of Questions. Insects 2021, 12, 262. [CrossRef] [PubMed]

28. Bruckermann, T.; Greving, H.; Schumann, A.; Stillfried, M.; Börner, K.; Kimmig, S.E.; Hagen, R.; Brandt, M.; Harms, U. To know about science is to love it? Unraveling cause-effect relationships between knowledge and attitudes toward science in citizen science on urban wildlife ecology. JRST 2021, 58, 1179-1202. [CrossRef] 
29. Interesse an Partizipativer Forschung in der Schweiz. Available online: https://www.fhnw.ch/de/forschung-unddienstleistungen/soziale-arbeit/integration-und-partizipation/interesse-an-partizipativer-forschung-in-der-schweiz (accessed on 17 July 2021).

30. Introducing "Doing It Together Science" an EU Citizen Science Project. Available online: https://uclexcites.blog/2016/04/29 /introducing-doing-it-together-science-an-eu-citizen-science-project/ (accessed on 30 July 2021).

31. Gevel, J.v.d.; Etten, J.v.; Deterding, S. Citizen Science Breathes New Life into Participatory Agricultural Research. A Review. Agron. Sustain. Dev. 2020, 40, 35. [CrossRef]

32. Balzer, S.; Züghart, W. Instrumente der Datenerhebung und Handlungsfelder zur Verbesserung der Datenlage zu Insekten im Naturschutz. Nat. Landsch. 2019, 4, 294-298. [CrossRef]

33. Frobel, K.; Schlumprecht, H. Erosion der Artenkenner. Abschlussbericht. 2014. Available online: https://docplayer.org/17743199 9-Erosion-der-artenkenner.html (accessed on 30 July 2021).

34. Güntert, S.T. Selbstbestimmung in der Freiwilligenarbeit. In Psychologie der Freiwilligenarbeit; Wehner, T., Güntert, S.T., Eds.; Springer: Berlin/Heidelberg, Germany, 2015; pp. 77-93. [CrossRef]

35. West, S.; Pateman, R. Recruiting and retaining participants in citizen science: What can be learned from the volunteering literature? Citiz. Sci. Theory Pract. 2016, 1, 1-10. [CrossRef]

36. Geoghegan, H.; Dyke, A.; Pateman, R.; West, S.; Everett, G. Understanding Motivations for Citizen Science. Final Report on Behalf of UKEOF, University of Reading, Stockholm Environment Institute (University of York) and University of the West of England 2016. Available online: http://www.ukeof.org.uk/resources/citizen-science-resources/MotivationsforCSREPORTFINALMay2 016.pdf (accessed on 17 July 2021).

37. Deci, E.L.; Ryan, R.M. The "what" and "why" of goal pursuits: Human needs and the self-determination of behavior. Psychol. Inq. 2000, 11, 227-268. [CrossRef]

38. Schäffer, N. The Royal Society for the Protection of Birds (GB). In Freiwilligenarbeit Im Naturschutz; Bremer, S., Erdmann, K.-H., Hopf, T., Eds.; Naturschutz und biologische Vielfalt; Bundesamt für Naturschutz: Bonn-Bad Godesberg, Germany, 2006.

39. Rotman, D.; Preece, J.; Hammock, J.; Procita, K.; Hansen, D.; Parr, C.; Lewis, D.; Jacobs, D. Dynamic Changes in Motivation in Collaborative Citizen-Science Projects. In Proceedings of the ACM 2012 Conference on Computer Supported Cooperative Work-CSCW '12, Seattle, WA, USA, 11-15 February 2012; ACM Press: Seattle, WA, USA, 2012; p. 217. [CrossRef]

40. Dickel, S.; Franzen, M. Digital Inclusion: The Social Implications of Open Science. Soziologie 2015, 44, 330-347. [CrossRef]

41. Eitzel, M.V.; Cappadonna, J.L.; Santos-Lang, C.; Duerr, R.E.; Virapongse, A.; West, S.E.; Kyba, C.C.M.; Bowser, A.; Cooper, C.B.; Sforzi, A.; et al. Citizen Science Terminology Matters: Exploring Key Terms. Citiz. Sci. Theory Pract. 2017, 2, 1. [CrossRef]

42. Jung, M. 2010 "Heimathirsche". Hobbyarchäologen zwischen Hedonismus und Professionalisierung; Waxmann: Münster, Germany, 2010.

43. Wikipedia: Bildungsbürgertum. Available online: https:/ / en.wikipedia.org/wiki/Bildungsbürgertum (accessed on 17 July 2021).

44. Vohland, K.; Göbel, C.; Balázs, B.; Butkevičienè, E.; Daskolia, M.; Duží, B.; Hecker, S.; Manzoni, M.; Schade, S. Citizen Science in Europe. In The Science of Citizen Science; Vohland, K., Land-Zandstra, A., Ceccaroni, L., Lemmens, R., Perelló, J., Ponti, M., Samson, R., Wagenknecht, K., Eds.; Springer International Publishing: Cham, Switzerland, 2021; pp. 35-53. [CrossRef]

45. Jeder Dritte Berliner Hat Gar Kein Wahlrecht. Available online: https://www.rbb24.de/politik/wahl/abgeordnetenhaus/agh-20 21/beitraege/wahlberechtigte-abgeordnetenhaus-bundestag-bezirksverordnetenversammlung-volksentscheid-26september2 021-auslaender-eubuerger-jugendliche-kinder-wahlrecht.html (accessed on 30 July 2021).

46. Liebenberg, L.; //Ao,/Am; Lombard, M.; Shermer, M.; Xhukwe,/Uase; Biesele, M.; //xao, D.; Carruthers, P.; Kxao, fOOma; Hansson, S.O.; et al. Tracking Science: An Alternative for Those Excluded by Citizen Science. Citiz. Sci. Theory Pract. 2021, 6, 1. [CrossRef]

47. Leiner, D.J. SoSci Survey Version 3.1.06-i [Computer software]. 2016. Available online: https://www.soscisurvey.de (accessed on 17 July 2021).

48. Bund Heimat und Umwelt Deutschland. Available online: https://bhu.de/mitglieder/ (accessed on 14 October 2021).

49. Sorensen, A.E.; Jordan, R.C.; LaDeau, S.L.; Biehler, D.; Wilson, S.; Pitas, J.-H.; Leisnham, P.T. Reflecting on Efforts to Design an Inclusive Citizen Science Project in West Baltimore. Citiz. Sci. Theory Pract. 2019, 4, 1. [CrossRef]

50. Hecker, S.; Bonney, R.; Haklay, M.; Hölker, F.; Hofer, H.; Goebel, C.; Gold, M.; Makuch, Z.; Ponti, M.; Richter, A.; et al. Innovation in Citizen Science-Perspectives on Science-Policy Advances. CSTP 2018, 3, 4. [CrossRef]

51. Vohland, K.; Weißpflug, M.; Pettibone, L. Citizen Science and the Neoliberal Transformation of Science-an Ambivalent Relationship. Citiz. Sci. Theory Pract. 2019, 4, 4. [CrossRef]

52. Verordnung (EU) 2016/679 des Europäischen Parlaments und des Rates vom 27. April 2016 zum Schutz natürlicher Personen bei der Verarbeitung personenbezogener Daten, zum freien Datenverkehr und zur Aufhebung der Richtlinie 95/46/EG (DatenschutzGrundverordnung). OJ L 119, 4.5.2016, p. 1-88. In force: This act has been changed. Current consolidated version: 04/05/2016. Available online: http:/ / data.europa.eu/eli/reg/2016/679/oj (accessed on 21 July 2021).

53. Museum für Naturkunde (2020), Leitfaden für rechtliche Fragestellungen in Citizen-Science-Projekten. Available online: https:/ / www.buergerschaffenwissen.de/sites /default/files / grid/2021/01/19/Citizen_Science_rechtlicher_Leitfaden_19.01. 2021_WEB.pdf (accessed on 17 July 2021). 
54. Hecker, S.; Garbe, L.; Bonn, A. The European citizen science landscape-A snapshot: Innovation in Open Science, Society and Policy. In Citizen Science: Innovation in Open Science, Society and Policy; Hecker, S., Haklay, M., Bowser, A., Makuch, Z., Vogel, J., Bonn, A., Eds.; UCL Press: London, UK, 2018; pp. 190-200. Available online: https://www.jstor.org/stable/j.ctv550cf2.20?seq=1\# metadata_info_tab_contents (accessed on 17 July 2021).

55. Hendriks, F.; Kienhues, D. Science Understanding between Scientific Literacy and Trust: Contributions from Psychological and Educational Research. In Science Communication; Leßmöllmann, A., Dascal, M., Gloning, T., Eds.; De Gruyter Mouton: Berlin, Germany, 2019; pp. 29-50. [CrossRef]

56. Bromme, R. Informiertes Vertrauen: Eine psychologische Perspektive auf Vertrauen in Wissenschaft. In Wissenschaftsreflexion. Interdisziplinäre Perspektiven zwischen Philosophie und Praxis; Jungert, M., Frewer, A., Mayr, E., Eds.; Mentis Verlag: Paderborn, Germany, 2020; pp. 105-134.

57. Moczek, N.; Koehler, J.K. Zur Zusammenarbeit zwischen akademischen und ehrenamtlichen Wissenschaftler*innen im CitizenScience-Projekt "Spurensuche Gartenschläfer". Umweltpsychologie 2020, 24, 200-221.

58. Salmon, R.A.; Rammell, S.; Emeny, M.T.; Hartley, S. Citizens, Scientists, and Enablers: A Tripartite Model for Citizen Science Projects. Diversity 2021, 13, 309. [CrossRef]

59. Lynch-O'Brien, L.I.; Babchuk, W.A.; Dauer, J.M.; Heng-Moss, T.; Golick, D. Transference of Citizen Science Program Impacts: A Theory Grounded in Public Participation in Scientific Research. Diversity 2021, 13, 339. [CrossRef]

60. Schaefer, T.; Kieslinger, B.; Brandt, M.; van den Bogaert, V. Evaluation in Citizen Science: The Art of Tracing a Moving Target. In The Science of Citizen Science; Vohland, K., Land-Zandstra, A., Ceccaroni, L., Lemmens, R., Perelló, J., Ponti, M., Samson, R., Wagenknecht, K., Eds.; Springer International Publishing: Cham, Switzerland, 2021; pp. 495-514. [CrossRef]

61. Nederhof, A.J. Methods of coping with social desirability bias: A review. Eur. J. Soc. Psych. 1985, 15, 263-280. [CrossRef]

62. Döring, N.; Bortz, J. Forschungsmethoden Und Evaluation in Den. Sozial- Und Humanwissenschaften; Springer-Lehrbuch; Springer: Berlin/Heidelberg, Germany, 2016. [CrossRef]

63. Skarlatidou, A.; Haklay, M. (Eds.) Geographic Citizen Science Design: No One Left Behind; UCL Press: London, UK, 2021. [CrossRef] 